\title{
The rate of technical change in Finnish agriculture, 1960 to 1990
}

\begin{abstract}
ERIC N. SiMS
SIMS, E. N. 1994. The rate of technical change in Finnish agriculture, 1960 to 1990. Agricultural Science in Finland 3: 151-160. (Agricultural Economics Research Institute, P.O. Box 3, FIN-00410 Helsinki, Finland. Present address: 114 Sherwood Drive, Santa Rosa, CA 95405, USA.)

The last major study of the productivity of Finnish agriculture using index numbers was completed in 1970. Since that study, there have been significant advances in duality theory and flexible functional forms. Similarly, the progress in the relationship between specific index numbers and production technologies has allowed a specific quantity index to be termed 'superlative.' The new techniques of measuring productivity are applied here to examine intertemporal productivity growth in Finnish agriculture from 1960 to 1990 . During the period examined, the average annual rate of technical change is $3.6 \%$. This rate is slightly greater than those reported for the U.K. and Ireland.
\end{abstract}

Key words: Finland, productivity, index numbers, technical change

\section{Introduction}

Technical change measures the effects of technological advancements on the production process. It is apparent that technical progress is not the result of a change in any one input. Further, attempts to measure technical change should address the impact of adjustments in all the inputs utilized in the production process. A proper estimate of the change is critical because, as USHER (1980) argues, the rate of technical change must be equal to the rate of economic growth. In 1980 The American Agricultural Economics Association Task Force on Measuring Agricultural Productivity recommended the use of an indexing procedure that does not impose a priori restrictions on the structure of production. The Task Force stated that 'the best approach [to productivity measurement] is the gross output/total input concept that the USDA currently uses in terms of meaning and applicability to concerns that peo- ple have when they ask about agricultural productivity' (U.S. Department of Agriculture 1980). In light of this endorsement, the new method to calculate technical change, based on index numbers, is applied to agricultural data from Finland to examine the variation in technical change from 1960 to 1990.

The following section of this paper, 'Historical Background,' includes a review of two prior studies that examine the productivity of Finnish agriculture. This review focuses on the substitutability of various inputs since this factor is the significant improvement in my methodology. In section two, 'Theory,' I rely on the theoretical results of Diewert to derive an index number formula to compute the technical change in Finland's agricultural sector. The data set utilized in the study is discussed in the third section, 'Data.' To determine the accuracy of the cost-based index, I compare my results to the actual performance of Finnish agriculture and conclude that the 
index does accurately model the increase in technical change. Section five, 'Analysis of Technical Change,' discusses general reasons for technical change and two reasons that are specific to Finland. Finally, in a 'Summary' I discuss my conclusions and draw attention to the need for future research.

\section{Historical background}

There are two empirical methods for examining the relationship between technical change and productivity. One is based on econometric techniques and the other utilizes index numbers. The first technique requires the specification of a production technology, such as a production, cost, or profit function. Then econometrics is used to estimate the function and obtain a parametric estimate of technical change and the type of change (i.e. neutral or biased). Hemilä (1982) used the constant elasticity of substitution, or CES, production function to estimate the parameters of technical change in Finnish agriculture. The second method requires an index of total output and an index of factor inputs. Total factor productivity is computed as the ratio of the output index to the input index. Ihamuotila (1971) used index numbers to study the productivity of Finnish agriculture from 1950 to 1969.

The production function is defined as the technical relationship between flows of services from stocks of labor and capital combining to produce a flow of output. For example, for each combination of capital (K) and labor (L) there is a unique output (Q).

$Q=f(K, L)$

Isoquants are used to show that different input combinations correspond to a unique output level. In production theory, the isoquants represent how easily one input may be substituted for another input. Perfect substitutes are inputs that can be exchanged without altering the output level. At the other extreme the inputs are known as perfect complements. In this case, the inputs are combined in fixed proportions. This type of production function is also referred to as the Leontief production function (CHAMBERS 1988).

The concept of marginal rate of technical substitution (MRTS) is critical to this study because the prior research concerning Finnish agricultural productivity has been based on production functions with very undesirable properties concerning input substitutability. The MRTS measures the rate that one input can be exchanged for another input without changing the total level of output. This study attempts to utilize a more realistic production function, it is called the homogeneous translog production function. The 'flexibility' of the translog function is that the elasticities of substitution for the various inputs can vary with the input levels. In contrast, Ihamuotila used a Laspeyres index which requires that all factors of production are perfect substitutes (the MRTS is infinite). Hemilä used a constant elasticity of substitution production function (CES). The CES production function constrains the elasticity of substitution for the inputs to be a constant regardless of the input levels. So, proportionate substitutability of inputs does not vary with movements in the relative prices of factor inputs. In addition to concerns about the substitution properties of a given production function, it is important to distinguish between movements along a production function and shifts of the function due to increased efficiency in input use. The shifting of a production function over time is one definition of technical change. In such a case, technical change is measured by examining changes in the output that are not attributable to any changes in the inputs.

In addition to production functions, technical change can be specified in terms of other functions. Because of the duality between the production function and profit and cost functions it is possible to derive other measures of technical change. In this study I will focus on the cost function because the statistical estimation of the unknown parameters that characterize technology is much more accurate using cost function techniques (DIEWERT 1989). Therefore, I consider the cost of producing a given output using 
various input bundles that change over time. So, I consider changes in costs not attributable to changes in input prices and output levels.

In recent years, the theory of index numbers has advanced significantly. Now, index numbers based on the continuous time Divisia index are preferred to those index numbers based on some arbitrary base year. HulTEN (1973) notes that 'while other indexes may do well, none does better' than the Divisia index. These index numbers are defined in continuous time by the following line integral:

$\log P_{t_{0}}^{t}=\Sigma \int_{t_{0}}^{t} c(t) d\left(\log p_{p}\right) ; \quad \Sigma c(t)=1$

where the $\mathrm{c}(\mathrm{t})$ is the proportion of different inputs in the total cost that must sum to one (see Törnqvist 1936). Divisia's formulation considers the continuous transition from one set of base prices (in $t_{0}$ ) to another set of current prices (in t). But, it is impossible to collect data that is continuous. So, discrete approximations of the Divisia index are used because they inherit many of the desirable properties of continuous index numbers. In this paper I will derive and apply a discrete time interval index to approximate the continuous time interval Divisia index. The methodology was advanced by Törnqvist, while he was at the Bank of Finland, to measure changes in the price level. This index will be used in this study to estimate the technical change of Finnish agriculture by measuring how the cost of producing a given output level, known as the unit output, has changed with the passage of time.

\section{Theory}

The goal of the economic theory of index numbers is to relate a particular index number formula to a specific functional form for each production function. The Laspeyres index formula is exact for a linear production function. However, this functional form has the undesirable property that all factors of production must be perfect substitutes. This, unfortunately, implies that if the relative price of any one input increases then the use of that input is terminated completely. The Törnqvist index is exact for the homogeneous translog production function. This production function is a second order approximation of any arbitrary twice differentiable homogeneous production function. DIEwERT (1976) has called index numbers that are exact for a specific functional form 'superlative' because of this advantage. Also, the translog is often called 'flexible' because it is able to approximate production functions with arbitrary substitution properties between the inputs.

To derive my index of technical change I will begin with the duality between the production function and the cost function. Assume the following cost function,

$\mathrm{C}=\mathrm{c}(\mathrm{w}, \mathrm{y}, \mathrm{t})$

where $\mathrm{C}$ is the total cost of production, $\mathrm{w}$ is a vector of input prices, $y$ is the level of total output, and $t$ indicates the time period. Output at time $t$ is:

$y=A(t) m(x)=f(x, t)$

where $\mathrm{m}(\mathrm{x})$ is the linearly homogeneous (i.e. constant returns to scale) production function exhibiting Hicks-neutral technical change and $\mathrm{A}(\mathrm{t})$ measures the scale of production through time. Chambers (1988) notes that technical change is defined as neutral if the MRTS is independent of time. In other words, the passage of time may shift the isoquants, but in doing so, the MRTS is not affected. This is incorporated into my model by allowing the scale parameter, A, to vary over time because this leaves the MRTS unaffected by technical change. These assumptions will allow me to derive an 'exact' index of technical change. Exact in the sense that my index number formula precisely represents a particular cost function.

Consider the following index of technical change:

$$
\frac{c_{t}(w, y, t)}{c_{0}(w, y, 0)} \text {. }
$$


This compares the cost of production of output $y$ in time period $t$ to the cost of production of output $\mathrm{y}$ in time period 0 , some arbitrary base period, assuming input prices are held constant at w. However, my calculation of technical change will be based on actual data where the input prices, output, and technology change over time. Therefore, I consider the ratio

$$
\frac{C(t)}{C(0)}=\frac{c\left(w_{p}, y_{p}, t\right)}{c\left(w_{0}, y_{0}, 0\right)} .
$$

Chambers has shown that if the cost function exhibits linear homogeneity in input prices and output and if the cost-minimizing input ratios are independent of the state of technology I can write:

$\frac{c\left(w_{i}, y_{t}, t\right)}{c\left(w_{0}, y_{0}, 0\right)}=\frac{y_{t} c\left(w_{t}\right) A(0)}{y_{0} c\left(w_{0}\right) A(t)}$

which implies

$\frac{A(0)}{A(t)}=\frac{C(t) y_{0} c\left(w_{0}\right)}{C(0) y_{t} c\left(w_{t}\right)}$

where all variables on the right-hand side are observable prices and quantities. And, the lefthand side is my index of technical change. To complete the derivation I must select a functional form for $\mathrm{c}$, the cost function. I assume that the component of the cost function that includes input prices is translog. This type of cost function is utilized since it is very general, or 'flexible,' and can approximate production structures with arbitrary substitution possibilities. The translog is written:

$\ln c(w)=\phi_{0}+\sum_{i} \phi_{i} \ln w_{i}+\frac{1}{2} \sum_{i} \sum_{j} \phi_{i j} \ln w_{i} \ln w_{j}$

Applying DIEWERT's (1976) quadratic lemma I obtain $\ln c\left(w_{0}\right)-\ln c\left(w_{t}\right)=$

$\frac{1}{2} \sum_{i}^{n}\left[\frac{\partial \ln c\left(w_{0}\right)}{\partial \ln w_{i}}+\frac{\partial \ln c\left(w_{i}\right)}{\partial \ln w_{i}}\right]\left[\ln w_{i 0}-\ln w_{i t}\right]$.

Then using the rules of logarithms and Shepard's lemma (SILBERBERG 1990) I know that if the firms are cost minimizers the input shares, denoted by $\mathrm{s}_{\mathrm{i}}$ for the $\mathrm{i}$ th inputs' share in the total cost, will be equal to the logarithmic derivatives of the cost function, so

$\frac{c\left(w_{0}\right)}{c\left(w_{t}\right)}=\prod_{i=1}^{n}\left(\frac{w_{i 0}}{w_{i t}}\right)^{\frac{1}{2}\left(S_{i 0}+S_{i t}\right)}$.

Combining my results yields

$$
\frac{A(0)}{A(t)}=\frac{C_{p} y_{0}}{C_{0} y_{t}} \prod_{i=1}^{n}\left(\frac{w_{i 0}}{w_{i t}}\right)^{\frac{1}{2}\left(S_{i 0}+S_{i t}\right)} .
$$

This is a 'superlative' index of technical change since it is an exact index for a translog technology. It is an index of technical change based on observed costs, output, and input prices. I will use this formula to calculate the index of technical change for Finnish agriculture in the Evaluation section.

\section{Data}

Total factor productivity is the ratio of an output index to an index of inputs and their respective costs and proportions in the production process. The inputs selected in this study were fertilizer (including lime), feed (including commercial feed concentrates), fuel and lubricants, machine and equipment expenses (including depreciation and maintenance), and building expenses (including depreciation, maintenance, and land improvements). In Finland depreciation is calculated from the replacement value using the straight-line method. Over the course of this study these specific inputs comprised $72 \%$ of the total expenses incurred by farmers (see Table 1 for the exact per- 


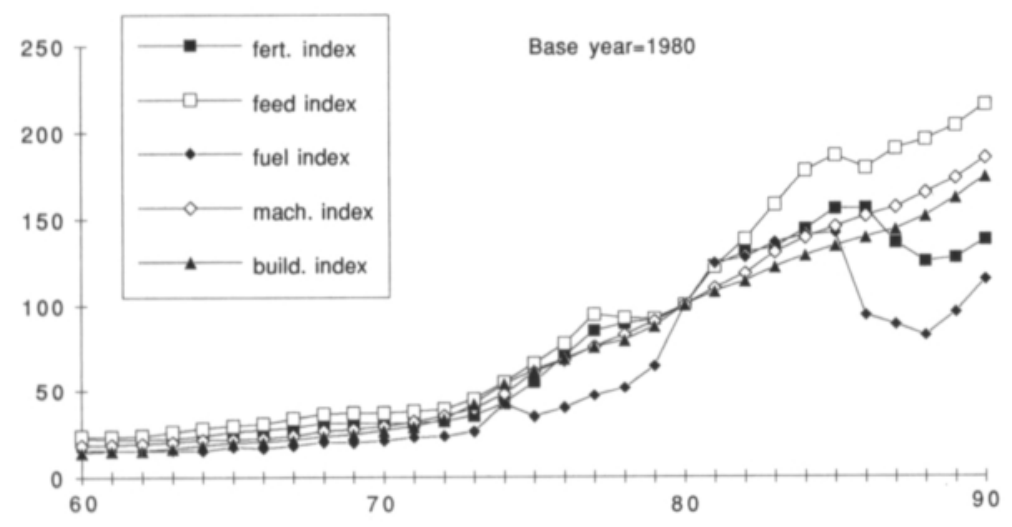

Real total costs and real outp

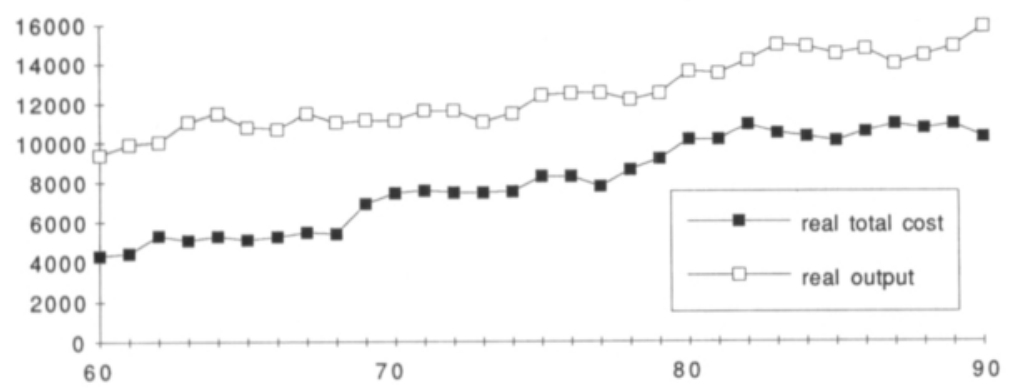

Figure 1. Individual input indices.

Figure 2. Real total costs and real output (FIM mil.). centage of costs included in the index for each year). One input, labor, was omitted from my study. However, the results will still be robust if the input costs excluded from those costs included in the estimation are quasi-fixed. VASAVADA and CHAMBERs (1986) conclude that 'labor, capital services, and land exhibited quasi-fixity while intermediate materials were a variable factor.' For this reason, my study has focused on those inputs that are the most variable factors.

The Agricultural Economics Research Institute (AERI) calculates a specific yearly price index for each of these five inputs published in the Statistics of Finnish Agriculture (1993). The index numbers are depicted in Figure 1 (with 1980 as the base year). Actual costs and total output are reported in the annual review of Finnish agriculture (KETTUNEN 1992). A time series of real total costs and real total output is included in Figure 2. Output consists of the total value of crop production, total animal production, and the total garden products (excluding ornamental plants) produced in a year plus the direct payments received by the farmer under government programs. Each input was deflated by its respective deflator, and output was deflated by the producer price index.

\section{Evaluation of the index of technical change}

Table 1 reports the cost-based index of technical change for Finnish Agriculture. The index is falling, for the most part, throughout the entire sample period (Figure 3 ). This implies that the per 
Unit Cost of Production (1960 $=100$

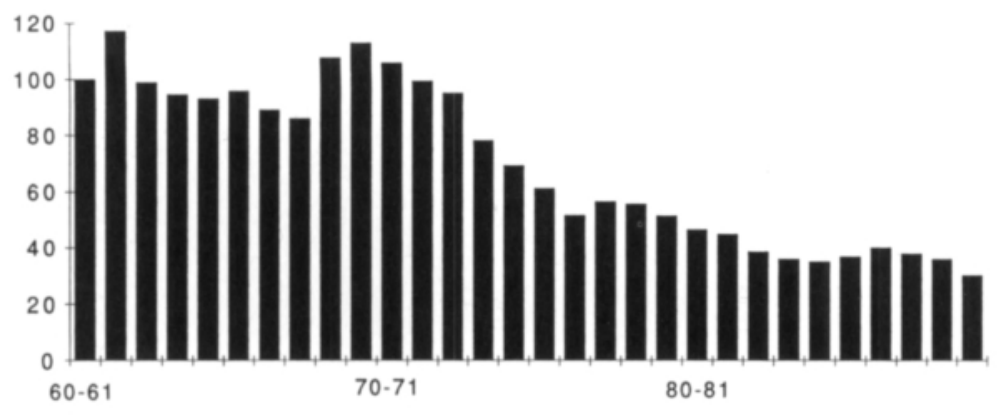

Figure 3. The unit cost of production $(1960=100)$ for Finnish agriculture. unit cost of production has decreased given constant input prices and constant total output. For example, the unit cost of output is 30 percent in 1990. This implies that in 1990 the output of 1960 could be produced for $30 \%$ of the cost incurred in 1960.

Reviewing the history of Finnish agriculture and the cost of production of unit output I am able to consider the accuracy of my index. This study overlaps the research of IHAMUOTILA (1971) for the period 1960 to 1969 . And, conveniently, I am able to utilize his research and history of Finnish agriculture to explain the sharp increase in costs in the periods 1961-1962 and 1968-1969. He notes 'the dramatic drop in productivity in 1962 which was affected by the crop failure in that year.' The large decrease in output is reflected, in my research methodology, as a significant increase in the cost-based index of technical change. The second noticeable increase in my index occurred in 1968-1969. Prior research notes two distinct reasons for this increase. First, Ihamuotila states that a "devaluation of Finnish currency was necessary, however, in late 1967. Agricultural prices increased somewhat more rapidly' thus increasing the total cost of production (and the index). Second, discussing his index of gross and net output of agriculture, Ihamuotila notes:

Allowing for variations between single years each of the data series [for the various classes of farms] indicates a slight rising trend in net output up to 1968 when each of them dropped by 20 percentage points. Examining the possible reasons for such a marked fall it should be noted that 1968 marked the change-over to a new system of taxation of agricultural income.

Before, taxes were based on income estimates determined by such factors as farm size and location. In contrast, the new tax system was based on actual income earned and expenditures incurred for each individual farm. Also, the depreciation rate was increased considerably in the new tax system. This had the impact, according to Ihamuotila, of making 'net output appear less than it was in real terms.' Again, this is seen as an increase, in this study, of the cost-based index of technical change. In addition, Hemilä (1982) includes a similar note in his study as he explains how the changes in the tax system made it very difficult for him to evaluate his econometric parameters measuring technological change in Finnish agriculture.

From 1970 to 1975 the unit cost of output declined slightly each year until the index drops significantly reflecting the record high output in 1976. Reviewing the history of Finnish agriculture for the period 1976 to 1990 I conclude that this period is also successfully modeled by the index derived in this study. Additional comments on each agricultural year from 1976 to 1990 are included in the appendix to allow further evaluation of the index. 
Table 1. Törnqvist index of the cost of unit output from 1960 to 1990 (with 1960 as the base year) and the percentage of specific costs with respect to total costs included in the construction of the index.

\begin{tabular}{lcc}
\hline Year $(1960=1)$ & $\begin{array}{c}\text { Cost of Unit } \\
\text { Output }\end{array}$ & $\begin{array}{c}\text { Percent of total } \\
\text { costs included }\end{array}$ \\
\hline $1960-1961$ & 1.00 & 62 \\
$1961-1962$ & 1.17 & 63 \\
$1962-1963$ & 0.99 & 65 \\
$1963-1964$ & 0.95 & 67 \\
$1964-1965$ & 0.93 & 67 \\
$1965-1966$ & 0.96 & 66 \\
$1966-1967$ & 0.89 & 67 \\
$1967-1968$ & 0.86 & 68 \\
$1968-1969$ & 1.08 & 69 \\
$1969-1970$ & 1.13 & 74 \\
$1970-1971$ & 1.06 & 72 \\
$1971-1972$ & 0.99 & 74 \\
$1972-1973$ & 0.95 & 74 \\
$1973-1974$ & 0.78 & 73 \\
$1974-1975$ & 0.69 & 75 \\
$1975-1976$ & 0.61 & 73 \\
$1976-1977$ & 0.51 & 74 \\
$1977-1978$ & 0.56 & 72 \\
$1978-1979$ & 0.56 & 74 \\
$1979-1980$ & 0.51 & 75 \\
$1980-1981$ & 0.47 & 70 \\
$1981-1982$ & 0.45 & 72 \\
$1982-1983$ & 0.39 & 71 \\
$1983-1984$ & 0.36 & 70 \\
$1984-1985$ & 0.35 & 69 \\
$1985-1986$ & 0.37 & 68 \\
$1986-1987$ & 0.40 & 67 \\
$1987-1988$ & 0.38 & 66 \\
$1988-1989$ & 0.36 & 66 \\
$1989-1990$ & 0.30 & 66 \\
\hline
\end{tabular}

\section{Analysis of technical change}

To examine the nature of the technical change in Finnish agriculture and the causes of the change it is necessary to consider a number of diverse explanations. HAYAMI and RUTTAN (1985) study the diffusion of agricultural technology in a careful study of the development of agriculture through time. They note that:

The Hicks theory of induced innovation implies that a rise in the price of one factor rela- tive to that of other factors induces a sequence of technical changes that reduces the use of that factor relative to the use of other factor inputs. As a result, the constraints on economic growth imposed by resource scarcity are released by technical advances that facilitate the substitution of relatively abundant factors for relatively scarce factors. [p. 85]

The index of technical change does not explain or highlight the exact factors that caused the increase in technical change in Finland from 1960 to 1990 . But, a typical list of reasons for the increase in productivity would include:
1. increased use of fertilizers
2. technological innovation
3. plant and animal breeding
4. improved feeding techniques
5. structural change
6. and, agricultural policies.

Two sources of technical change, particular to Finland, are interesting to consider in greater detail. One factor affecting the rapid increase in the productivity growth is a result of the structural change in Finnish agriculture after World War Two. After the armistice agreement with the Soviet Union in 1944 Finland was forced to cede territory, including 300,000 hectares of farm land, to the Soviet Union. Shortly thereafter, in 1945, The Land Acquisition Act was passed (WESTERMARCK 1954). Finnish Farmers that had been forced to cede farm holdings to the Soviet Union were entitled to land in Finland. In addition, the Act made land available to all ex-service men, war widows, and orphans. A significant result of the Act was that the average size of Finnish farms fell and the number of farms increased (Table 2). The small size of the farms has hampered the mechanization of Finnish agriculture. Recently, as farm size has increased so has the rate of technical change (Table 3 ). When the total time span examined is broken into smaller segments I note that in the early period (1960-1970) technical change was actually regressive (also likely due to reasons discussed in the Evaluation section). 
Table 2. Acreage, the number of farms and the average size of the farms in 1941-1990.

\begin{tabular}{lccc}
\hline & $\begin{array}{c}\text { Arable Land } \\
1,000 \text { ha }\end{array}$ & $\begin{array}{c}\text { Number of farms } \\
1,000\end{array}$ & $\begin{array}{c}\text { Average size } \\
\text { ha }\end{array}$ \\
\hline 1941 & 2,296 & 245.8 & 9.4 \\
1950 & 2,431 & 305.3 & 8.0 \\
1959 & 2,633 & 331.3 & 7.9 \\
1969 & 2,699 & 297.3 & 9.0 \\
1975 & 2,501 & 248.7 & 10.1 \\
1980 & 2,463 & 224.7 & 11.0 \\
1985 & 2,420 & 200.5 & 12.1 \\
1990 & 2,544 & 199.4 & 12.8 \\
\hline
\end{tabular}

Source: KeTTUNEN 1993. p. 13

Table 3. Average Annual Change in technical change for selected periods (A negative number implies an increase in technical change).

\begin{tabular}{lc}
\hline Period & Average Returns \\
\hline $1960-1990$ & $-3.6 \%$ \\
$1960-1970$ & $1.2 \%$ \\
$1971-1980$ & $-7.6 \%$ \\
$1981-1990$ & -4.4 \\
\hline
\end{tabular}

In contrast, during the later stages of the study, as consolidation of farms has increased, which promotes economies of scale and mechanization, I see a rapid increase in the rate of technical change.

The second point of interest is that the average annual technical change for the 1981-1990 period is less than the rate for the 1971-1980 period. This is probably a result of the constraints imposed on agriculture by the production control measures applied in Finland in the 1980s. This is the period when regulations on reducing milk production came into effect. Dairying is the largest sector in Finnish agriculture. These regulations include a production quota for milk, a regulation limiting the number of dairy cows to only twenty on new farms, and a bonus system that awards decreases in production of 15 per cent (or 5000 liters per year). Kola (1991) outlines the exact nature of the measures and reports the specific dates that the regulations were implemented.

\section{Summary}

In this study I have constructed a cost-based index of technical change. It is based on the Törnqvist index that has been shown to be exact for the translog cost function. Data were collected on Finnish agriculture for the period 1960 to 1990. The results indicate that throughout the period the average annual change in technical change was $3.6 \%$. This means that the costs incurred would fall during that period of time if input prices and output were held constant. Similar studies by ThiRTLE and BotTomLey (1992) for the U.K. and Glass and MCKILlop (1990) for Ireland report rates of $1.9 \%$ and $2.54 \%$, respectively. Also, a brief overview of the recent history of Finnish agriculture is included in the examination. This allows me to compare the path of the cost-based productivity index to the actual performance of the Finnish agricultural sector. It is apparent that the index accurately reflects the reality that occurred within the agricultural sector. Lastly, I am able to consider the average annual rate of technical change for the entire period examined and various sub-periods. High rates of technical change are associated with economies of scale and mechanization in the 1970s. The rate has begun to decrease recently due to the impact of strict production control measures within the agricultural sector in Finland.

All studies that attempt to calculate technical change, regardless of the sector or country reviewed, face similar difficulties that may cause bias in the results. It is impossible to consider an increase in the quality of an input or output through time or the introduction of a new input or output during the period examined (e.g. organic fertilizer or organic produce in the present study). Also, certain inputs and outputs have been omitted and this may cause 'exclusion bias.' Lastly, the index number formula for technical change is derived based on the microeconomics of the firm. Then, industry wide data are used in the calculations giving rise to the potential for an error known as 'aggregation over firms bias.' All researchers address these concerns in a unique way so there is a great diversity in methodology 
and direct comparisons of different studies is meant to be illustrative rather than definitive. Future research is needed to expand the scope of the inputs and outputs included in the study of technical change in Finland. This will greatly improve their accuracy and usefulness. Finally, in conclusion, there is great potential to utilize data that has been systematically collected, using the exact same methodology, for various countries that will allow direct and definitive comparisons of technical change, growth, and performance.

\section{References}

Chambers, R. 1988. Applied Production Analysis. 331 p. Cambridge University Press.

DIEWERT, E. 1976. Exact and Superlative Index Numbers. Journal of Econometrics 4, 1: 115-146.

- 1989. The Measurement of Productivity. 60 p. Discussion Paper No. 89-04, Department of Economics, University of British Columbia.

Glass, J.C. \& McKILlop, D.G. 1990. Production Interrelationships and Productivity Measurement In Irish Agriculture. European Review of Agricultural Economics 17, 3: 271-287.

Hayami, Y., \& RutTaN, V. 1985. Agricultural Development: An International Perspective. 512 p. Baltimore: Johns Hopkins Univ. Press.

HemiLÄ, K. 1982. Measuring Technological Change in Agriculture: An Application Based on the CES Production Function. 223 p. Journal of the Scientific Agricultural Society of Finland 54: 165-223.

Hulten, C. 1973. Divisia Index Numbers. Econometrica 41, 6: 1017-1024.

Ihamuotila, R. 1971. Productivity and the Aggregate Production Function in the Finnish Agricultural Sector, 1950-1969. 104 p. Working paper of the Agricultural Economics Research Institute of Finland, No. 25.

Kettunen, L. 1992. Review of Finnish Agriculture. Agriculture Economics Research Institute, Helsinki, Finland.

- 1993. General Conditions of Agriculture and Problems of Integration. In: Kettunen, L. (ed.). Finnish Agriculture and European Integration. 120 p. Agricultural Eco- nomics Research Institute Publications No. 71. Helsinki.

KolA, J. 1991. Production Control of Finnish Agriculture. 133 p. Agricultural Economics Research Institute Publications No. 64. Helsinki.

SilberberG, E. 1990. The Structure of Economics. A Mathematical Analysis. 686 p. McGraw-Hill, New York.

Statistics of Finnish Agriculture 1993. Agricultural Economics Research Institute. Helsinki, Finland. 33 p.

Thirtle, C. \& Botтomley, P. 1992. Total Factor Productivity in UK Agriculture, 1967-1990. Journal of Agricultural Economics 43, 3: 381-400.

TÖRnQvist, L. 1936. The Bank of Finland's Consumption Price Index. Bank of Finland Monthly Bulletin, No. 10. p. $1-8$.

U.S. Department of Agriculture 1980. Economics, Statistics, and Cooperative Service. Measurement of U.S. Agricultural Productivity: A review of Current Statistics and Proposals for Change. NED Tech. Bull. No. 1614, Washington, DC.

UsHeR, D. 1980. The Measurement of Economic Growth. 306 p. Basil Blackwell, Oxford.

VAsAVADA, U. \& Chambers, R. 1986. Investment in U.S. Agriculture. American Journal of Agricultural Economics 68, 4: 950-960.

Westermarck, N. 1954. Finnish Agriculture. 85 p. Helsinki: Pellervo Society.

Manuscript received August 1993 


\title{
SELOSTUS
}

\section{Suomen maataloustuotannon teknisen mutoksen nopeus 1960-1990}

\author{
ERIC N. SIMS \\ Maatalouden taloudellinen tutkimuslaitos
}

Edellinen laaja tutkimus Suomen maataloustuotannon tuottavuudesta käyttäen indeksilukuja valmistui 1970. Duaaliteoriaa ja joustavia funktiomuotoja on kehitetty merkittävästi mainitun tutkimuksen jälkeen. Samoin indeksilukujen ja tuotantoteknologioiden vălisessä riippuvuussuhteessa tapahtuneen kehityksen ansiosta on voitu määritellä tietty määräindeksi kaikkia muita paremmaksi. Tässă tutkimuksessa sovellettiin uusia tuottavuuden mittaamistekniikkoja Suomen maataloustuotannon tuottavuuden kasvun selvittämiseksi vuosien 1960 ja 1990 välisenä aikana. Keskimääräinen vuosittainen teknisen muutoksen nopeus oli tutkimusajanjaksona 3,6 \%. Muutosvauhti on hieman suurempi kuin vastaavat luvut Iso-Britanniasta ja Irlannista.

\section{Appendix}

To evaluate the accuracy of the cost-based index of technical change it is useful to compare the overall output of a given year to the movement of the index I have computed. For the period 1960 to 1971 see the analysis in the Evaluation section. It explains the distinct increases in the index in 1962 and 1968 (Figure 3). For the period 1976 to 1990 I am able to compare the index to a brief overall evaluation of the agricultural year. For example, the crop failure of 1987 is seen as an increase in a cost-based index of technical change.

Lauri Kettunen's comment on the agriculture year quoted from the annual Review of Finnish Agriculture published each year since 1978:

In 1976 the yield was a record high and in 1977 much below normal.

The 1978 harvest was about normal or slightly below normal.

The yield in 1979 was about normal.

In 1980 the yields of crops per hectare were in general either normal or slightly above the expected value.
Agriculture experienced serious crop damage in the summer of 1981.

Agricultural yields were good, in terms of both quantity and quality, in 1982.

Agriculture had a record yield in 1983 .

In 1984, agricultural development was favorable and the total yield was rather good.

Harvests were good overall for farmers in 1985.

Development in agriculture continued rather stable and satisfactory in 1986.

In the summer of 1987 agriculture was met with a very serious crop failure (on average the crop level was $34 \%$ smaller than in 1986).

Like in 1987, the yield level remained clearly below the normal in 1988.

Finnish farmers can be very satisfied with the year 1989 . The yield hit the all-time record.

1990 was a good year for agriculture in Finland. The yield was a record high, and quality was also good. 